\title{
Assessment of heavy metals uptake in leafy vegetables grown on long term wastewater irrigated soil across Vrishabhavathi River, Bangalore, Karnataka.
}

\author{
Jayadev $^{1}$, E.T. Puttaih ${ }^{2}$ \\ ${ }^{1}$ Research scholar, Department of Environmental Science, Kuvempu University, Karnataka. \\ ${ }^{2}$ Professor, Department of Environmental Science, Kuvempu University, Karnataka and Vice Chancellor, \\ Gulbarga University, Gulbarga.Karnataka.
}

\begin{abstract}
The green leafy vegetables such as Spinach, Fenugreek, Amaranthus randomly collected from agricultural fields across Vrishabhavathi river at five different stations were analysed for heavy metals $\mathrm{Fe}, \mathrm{Zn}$, $\mathrm{Cd}, \mathrm{Cr}, \mathrm{Cu}, \mathrm{Mn}$, and $\mathrm{Pb}$ using atomic absorption spectrophotometer. The wastewater sample analyzed at these stations shows higher Electrical Conductivity, BOD, COD and low dissolved oxygen. The heavy metal concentration was higher over year by year in urban sewage water used for irrigation. The results shows higher concentration of iron content in plants followed by manganese. Chromium content is lower in leafy vegetable species. Spinach has higher transfer factor for the heavy metals among the three leafy vegetables followed by Fenugreek and Amaranthus. Highest transfer factor is recorded for zinc metal followed by manganese. Lowest transfer factor is recorded for chromium and lead. The average transfer factor observed in the selected green leafy vegetables is in the order of $\mathrm{Zn}>\mathrm{Mn}>\mathrm{Fe}>\mathrm{Cu}>\mathrm{Ni}>\mathrm{Pb}>\mathrm{Cr}$.
\end{abstract}

Key words: Heavy metals, Transfer factor, Urban waste water, leafy vegetables.

\section{Introduction:}

The soil contaminated with heavy metals is steadily increasing around the world especially in urban areas. In urban areas, where no alternative source of clean water exists, people will adopt Urban Waste Water(UWW) for irrigation of agriculture fields. The use of UWW increases the productivity of crops due to presence of major essential plant nutrients[1,2,3,4].The UWW also contains variable amounts of heavy metals such as $\mathrm{Pb}, \mathrm{Ni}, \mathrm{Cd}, \mathrm{Cu}, \mathrm{Zn}, \mathrm{Mn}$ and $\mathrm{Cr}$ [5]. The vegetables are rich in important minerals, carbohydrates, proteins, vitamins and trace elements which have marked health effect[6]. The consumption of these vegetables is one of the most important pathways by which heavy metals enter the food chain[7]. The contaminated leafy vegetables pose a significant health risk to humans. The nature of effects can be toxic, neuro toxic, Carcinogenic and becomes apparent only after several years of exposure, as there is no good mechanism for their elimination from the human body $[8,9]$. The study by number of researchers shows that elevated level of heavy metals presence in vegetables grown in areas where UWW is used for long term irrigation $[2,10,11]$. The continuous consumption of heavy metals through metal contaminated vegetables also depletes some of the essential nutrients in the body causing a decrease in immunological defenses, intrauterine growth retardation etc. [12].The soil gets polluted due to continuous use of UWW for irrigation and absorbed heavy metals by vegetables grown on these fields settles in edible tissue of the vegetables [13].

\section{Materials and Methods}

Study area: Bangalore is located at a latitude $12.58^{\prime} \mathrm{N}$ and longitude of $77.35^{\prime} \mathrm{E}$ at an altitude of $921 \mathrm{~m}$ above mean sea level [13].Vrishabhavathi River is one of the tributaries of the river Cauvery. It carries largest drainage watersheds out of three viz., Vrishabhavathi, Bellandur, and Nagavara watersheds. The Vrishabhavathi watershed carries polluted effluents of two major industrial areas viz. Peenya and Rajajinagar and domestic sewage effluents (both treated and untreated) directly discharged into it from a large part of city. It also carries Industrial effluents along Bangalore-Mysore State Highway factories and Bidadi Industrial area. The sampling stations selected were highly contaminated due to the addition of raw UWW and industrial effluent to the polluted river[14]. The UWW is used for irrigation in this stretch from several decades. The heavy metal contamination and transfer factor assessment was conducted in this area, since the vegetables are likely to pose a greater threat to human health through food chain.

\section{Sampling and analysis}

The sampling stations were chosen to study heavy metal concentration in leafy vegetables like Spinach, Fenugreek and Amaranthus, where the sewage water is directly used for agriculture purpose from past several years. Five stations were identified at different sites along Vrishabhavathi river valley and were shown in 
fig.1 during the study period. Samples of Spinach, Fenugreek and Amaranthus collected from different fields representing different areas of study area. The Plant samples were washed with water and then by distilled water to remove soil and airborne pollutants. The edible parts of the plants were sliced into small pieces and air-dried in the laboratory for two to three days to reduce the water content. Thereafter, they were dried in a hot air oven around 70 to $80^{\circ} \mathrm{C}$ till all the moisture content was removed. Dried samples were powdered using pestle and mortar and sieved through 1-mm nylon mesh. The dried soil and plant samples of $1 \mathrm{gm}$ from sieved is digested in $10 \mathrm{~cm}^{3}$ of concentrated nitric acid with distilled water till all the black residue turns colorless at about $200^{\circ} \mathrm{C}$ in fuming chamber. The samples were filtered through Whatman filter no.42 filter paper with repeated washing with distilled water and the filtered sample is diluted up to $100 \mathrm{ml}$ using distilled water. The samples were analyzed for heavy metals using Atomic Absorption Spectrophotometer (GBC Avantra Version1.31).

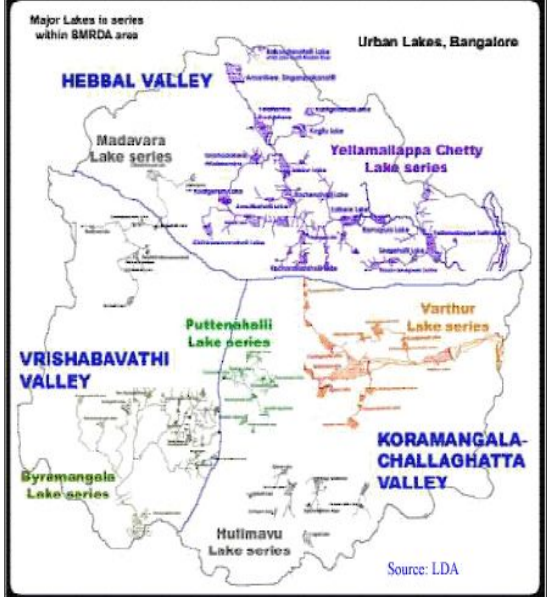

Vrishabhavathi water shed, Bangalore

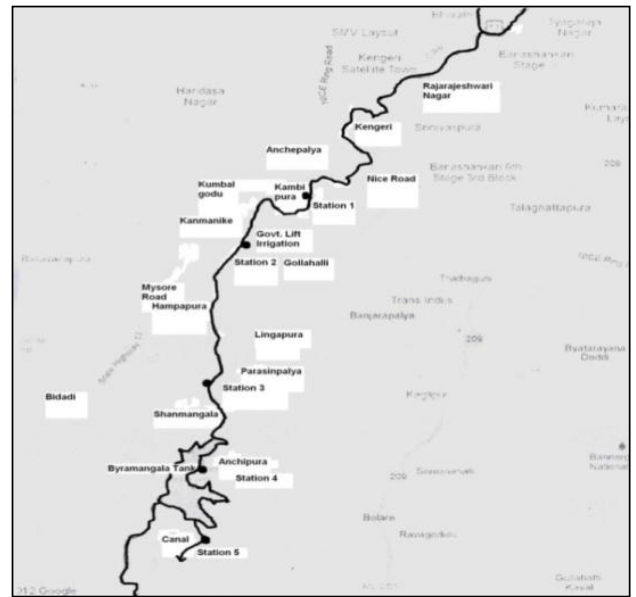

Sampling Stations at Vrishabhavathi valley

Station-1:Kambipura, Station-2:Gollahalli, Station-3:Shanmangala, Station-4:Anchipura, Station-5: Canal from byramangala tank.

\section{Results and conclusion:}

The edible part of the vegetables and soil samples were collected from all five sampling stations and analyzed for heavy metal concentration using atomic absorption spectroscopy. The concentration of heavy metals in soil was in the order of $\mathrm{Fe}>\mathrm{Mn}>\mathrm{Zn}>\mathrm{Cu}>\mathrm{Ni}>\mathrm{Cr}>\mathrm{Pb}$ [15]. Cadmium was below the detectable limit. The results of heavy metal concentration in vegetables are tabulated in tables 1.1,1.2 and1.3.

As can be seen from table 1.1 among heavy metals analyzed, iron is found to contribute highest to the metal content in amaranthus plant. Iron is followed by manganese and least is chromium. The copper is varied from 1.3 to $16 \mathrm{mg} / \mathrm{kg}$ across the stations. Nickel has registered a variation from 4.5 to $11.9 \mathrm{mg} / \mathrm{kg}$. Cadmium below detectable level in all three samples. The concentration of heavy metals present in the order of $\mathrm{Fe}>\mathrm{Zn}>\mathrm{Mn}>\mathrm{Cu}>\mathrm{Ni}>\mathrm{Pb}>\mathrm{Cr}$. Singh [16] showed that irrespective of crop the average metal content was in the order of $\mathrm{Zn}>\mathrm{Cu}>\mathrm{Pb}>\mathrm{Ni}>\mathrm{Cd}$. The transfer factor for amaranthus species is in the order of $\mathrm{Zn}>\mathrm{Mn}>\mathrm{Fe}>\mathrm{Cu}>\mathrm{Ni}>\mathrm{Pb}>\mathrm{Cr}$ as shown in figure 2. Similar variation of heavy metals are reported by Singh and Pandey $[17,18]$.

Fenugreek plant sample metal content values are tabulated in table 1.2. The metal concentration is higher compared to amaranthus species. For instance copper varies from 2.1 to $20.1 \mathrm{mg} / \mathrm{kg}$ and lead from 1.0 to $8.4 \mathrm{mg} / \mathrm{kg}$. The concentration of heavy metals present in the order of $\mathrm{Fe}>\mathrm{Zn}>\mathrm{Mn}>\mathrm{Cu}>\mathrm{Ni}>\mathrm{Pb}>\mathrm{Cr}$. The transfer factor observed is similar to amaranthus plant.

The spinach shows highest metal concentration compare to other two leafy vegetables [19]. The copper concentration varies from 2.1 to $20.1 \mathrm{mg} / \mathrm{kg}$, lead between 0.9 to $8.2 \mathrm{mg} / \mathrm{kg}$, Zinc 36 to $75 \mathrm{mg} / \mathrm{kg}$, Nickel 5.9 to $14.9 \mathrm{mg} / \mathrm{kg}$, Chromium 1.5 to $15.6 \mathrm{mg} / \mathrm{kg}$, Iron 212 to $235 \mathrm{mg} / \mathrm{kg}$ and Manganese from 23.5 to $75.5 \mathrm{mg} / \mathrm{kg}$ (table 1.3). The concentration of heavy metals present in the order of $\mathrm{Fe}>\mathrm{Zn}>\mathrm{Mn}>\mathrm{Cu}>\mathrm{Ni}>\mathrm{Pb}>\mathrm{Cr}$. In all three types of leafy vegetables and soil samples analyzed at these stations, concentration was higher at station 3 and 4 this is due to addition of new sewage and industrial waste from Bidadi as well as industries along the Mysore Bangalore highway. 
Table 1.1: Concentration of Heavy Metals(mg/kg of dry weight) inAmaranthus

\begin{tabular}{|c|c|c|c|c|c|c|c|}
\hline Sample & $\mathrm{Cu}$ & $\mathrm{Pb}$ & $\mathrm{Zn}$ & $\mathrm{Ni}$ & $\mathrm{Cr}$ & $\mathrm{Fe}$ & $\mathrm{Mn}$ \\
\hline Station 1 & 7.2 & 6.1 & 82.7 & 5.0 & 1.2 & 185 & 47 \\
\hline Station 2 & 1.3 & 6.0 & 40 & 4.8 & 1.25 & 201 & 68 \\
\hline Station 3 & 16 & 0.9 & 55 & 11.9 & 10 & 215 & 44 \\
\hline Station 4 & 11 & 8 & 69 & 10.2 & 7.5 & 211 & 24 \\
\hline Station 5 & 8.2 & 1.1 & 45 & 4.5 & 1.1 & 215 & 21.5 \\
\hline
\end{tabular}

Table 1.2: Concentration of Heavy Metals $(\mathrm{mg} / \mathrm{kg}$ of dry weight) in Fenugreek

\begin{tabular}{|c|c|c|c|c|c|c|c|}
\hline SampleStations & $\mathrm{Cu}$ & $\mathrm{Pb}$ & $\mathrm{Zn}$ & $\mathrm{Ni}$ & $\mathrm{Cr}$ & $\mathrm{Fe}$ & $\mathrm{Mn}$ \\
\hline Station 1 & 8.3 & 7.5 & 76 & 6.4 & 1.4 & 210 & 54 \\
\hline Station 2 & 2.1 & 8.0 & 41 & 6.5 & 1.6 & 232 & 79 \\
\hline Station 3 & 20.1 & 1.0 & 60 & 14.9 & 15.8 & 225 & 51 \\
\hline Station 4 & 15.9 & 8.4 & 72.5 & 12.8 & 8.9 & 224 & 29.3 \\
\hline Station 5 & 9.2 & 1.2 & 38.3 & 6.1 & 1.7 & 218 & 24.0 \\
\hline
\end{tabular}

Table 1.3: Concentration of Heavy Metals ( $\mathrm{mg} / \mathrm{kg}$ of dry weight) in Spinach

\begin{tabular}{|c|c|c|c|c|c|c|c|}
\hline SampleStations & $\mathrm{Cu}$ & $\mathrm{Pb}$ & $\mathrm{Zn}$ & $\mathrm{Ni}$ & $\mathrm{Cr}$ & $\mathrm{Fe}$ & $\mathrm{Mn}$ \\
\hline Station 1 & 9.0 & 7.5 & 75 & 5.9 & 1.5 & 212 & 51 \\
\hline Station 2 & 2.1 & 8.0 & 40 & 6.3 & 1.55 & 235 & 75.5 \\
\hline Station 3 & 20.1 & 0.9 & 56 & 14.9 & 15.6 & 229 & 50.9 \\
\hline Station 4 & 15.3 & 8.2 & 68 & 12.9 & 8.9 & 221 & 28 \\
\hline Station 5 & 9.1 & 1.4 & 36 & 6.3 & 1.45 & 217 & 23.5 \\
\hline
\end{tabular}

\section{Transfer factor:}

One way of approach to access the mobility of metal from soil to plants is by calculating the transfer factor (TF), which is given by the following equation $[20,21]$

$$
\mathrm{TF}=\mathrm{C}_{\text {Plant }} / \mathrm{C}_{\text {Soil }}
$$

where $C_{\text {Plant }}$ is the concentration of metal content in plant species and $\mathrm{C}_{\text {Soil }}$ is the metal concentration of the metal in soil $(\mathrm{mg} / \mathrm{kg}$ dry weight).Based on the transfer factor of various heavy metals by the select leafy vegetables grown with UWW following interpretations can be made. Spinach has higher transfer factors for the heavy metals except zinc, among all the three leaf vegetables. Spinach is followed by the Fenugreek and Amaranths. For copper, lead, nickel, chromium, iron and manganese is spinach followed by Fenugreek and amaranthus. For zinc, amaranthus followed by spinach and fenugreek recorded higher transfer factors. Highest Transfer Factor is recorded for the Zinc metal followed by the Manganese. Lowest Transfer Factor is recorded in Chromium and Lead. The average values of transfer factor for three leaf vegetables is shown in the fig.2 Soil to plant transfer factor varies from $\mathrm{Zn}>\mathrm{Mn}>\mathrm{Fe}>\mathrm{Cu}>\mathrm{Ni}>\mathrm{Pb}>\mathrm{Cr}$ [21] showed the transfer factor values decreases from $\mathrm{Mn}>\mathrm{Zn}>\mathrm{Cd}>\mathrm{Cu}>\mathrm{Pb}$.

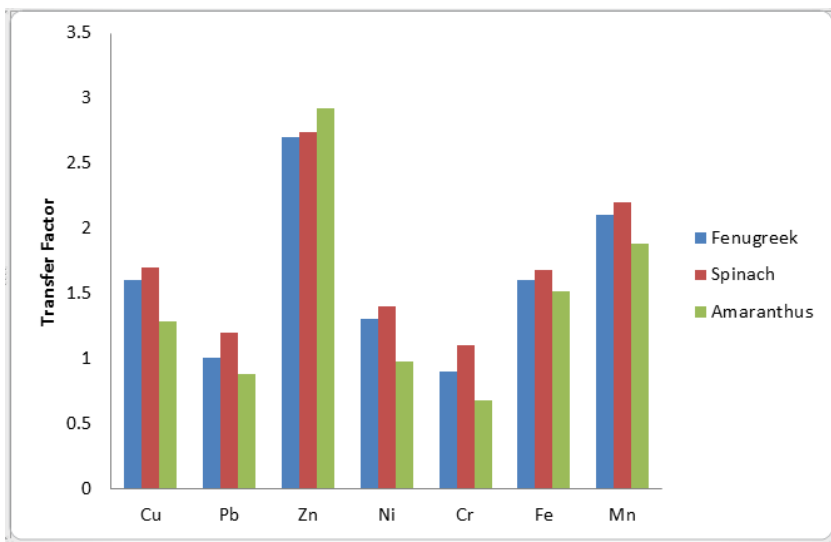

Figure 2: Transfer Factor of Heavy Metals in Leaf Vegetables 


\section{Conclusion:}

It can be concluded from the study that, the metal concentration is higher at highly polluted area and uptake depends on the level of concentration in soil media. The metal $(\mathrm{Cu}, \mathrm{Pb}, \mathrm{Zn}, \mathrm{Ni}, \mathrm{Cr}, \mathrm{Fe}, \mathrm{Mn})$ concentration in Amaranthus, Fenugreek and Spinach depend on the concentrations of the metal in soil sample in which the plants are grown. Comparatively $\mathrm{Zn}$ and $\mathrm{Mn}$ were easily mobilized from soil to plants and observed more accumulation compared to other metals. The transfer factor decreases in the order of $\mathrm{Zn}>\mathrm{Mn}>\mathrm{Fe}>\mathrm{Cu}>\mathrm{Ni}>\mathrm{Pb}>\mathrm{Cr}$. The study reveals that the consumption of these contaminated leafy vegetables may lead to increased health hazards.

\section{References}

[1]. MitraA and Gupta L.K, Effect of sewage water irrigation on essential plant nutrient and pollutant element status in a vegetable growing area around Calcutta, Journal of the Indian Society of Soil Science 47,1999, 99-105.

[2]. Singh K.P., Mohan D., Sinha S., \&Dalwani R., Impact assessment of treated / untreated wastewater toxicants discharged by sewage treatment plants on health, agricultural, and environmental quality in the wastewater disposal area. Chemosphere, 55,2004, 227-255

[3]. Tiwari R.C., Saraswat P.K. andAgarwal H.P., Changes in micronutrients status of soils irrigated with treated sewage water and tube well water, Journal of Indian society of soil science 51, 2003,150-155.

[4]. Jayadev and Puttaiah E.T., Studies onheavy metals contamination in Vrishabhavathiriver water and ground water of the surrounding river, International Journal of Scientific and Engineering Research, Vol. 4, Issue 1,2013,p1-9.

[5]. Kaushal F.L., Parwana H.K. and Varma S.P., Effect of waste water irrigation on soil properties, Indian journal of Environmental protection 13, 1993, 374-378.

[6]. Arai S, Global view on functional foods: Asian perspectives. Br J Nutur 88: (2002). 139-143.

[7]. Wang X.L., Sato T, Xing BS, Tao S, Health risks of heavy metals to the general public in Tianjin, China via consumption of vegetables and fish. Science of the Total Environment 350: 2005,28-37.

[8]. Amlan Kr. Ghosh, Bhatt M.A, Agrawal H.P, Effect of long-term application of treated sewage water on heavy metal accumulation in vegetable grown in northern India, Environ Monit Assess ,184: 2012, 1025-1036.

[9]. Gupta N., Khan D.K., Santra S.C, Heavy metal accumulation in vegetables grown in a long-term wastewater irrigated agricultural land oftropical India Environ Monit Assess , 184: 2012, 6673-6682.

[10]. Sharma R.K.,Agarwal M., Marshal F, Heavy metal contamination in vegetables grown in wastewater irrigated areas of Varanasi,India. Bull Environ Contam. Toxicol 77: (2006), 312-318.

[11]. Sharma R.K.,Agarwal M., Marshal F, Heavy metal contamination of soil and vegetables in suburban areas of Varanasi, India. Ecotoxicol. Environ. Saf. 66: (2007), 258-266.

[12]. Manu Arora, BalaKiran, Shewata Rani, Anchal Rani, BarinderKaun, NeerajMittal,Heavy Meal accumulation in vegetables irrigated with water from different sources. Food Chemistry. 111. (2008): 811-815.

[13]. Lokeshwari H and Chandrappa G T, Impact of heavy metal contamination of Bellandur Lake on soil and cultivated vegetation. Current Science, 91: (2006),p 622 - 627.

[14]. Paul Popa, MihaelaTimofti, MirelaVoiculescu, Silvia Dragan, CatalinTrif and Lucian P Georgescu, Study of Physico-Chemical charecteristics of waste water in an Urban Agglomeration in Romania. The Scientific World Journal, Vol.2, 2012, Article ID 549028.

[15]. Jayadev, E.T. Puttaih, Heavy Metal Contamination In Soil Under The Application Of Polluted Sewage Water Across Vrishabhavathi River ,IJERA, Vol. 2, Issue 6, 2012, pp.1666-1671.

[16]. Singh S., Zacharias M, Kalpana S and Mishra S ,Heavy metals accumulation and distribution pattern in different vegetable crops Journal of Environmental Chemistry and Ecotoxicology Vol. 4(4), (2012), pp. 75-81.

[17]. Singh S, Kumar M ,Heavy metal load of soil, water and vegetables in peri -urban Delhi. Environ. Monit. Assess. 120: (2006), p7990.

[18]. Pandey J, Pandey U, Accumulation of heavy metals in dietary vegetables and cultivated soil horizon in organic farming system in relation to atmospheric deposition in a seasonally dry tropical region of India. Environ Monit Assess. 2009 Jan; 148(1-4):61-74.

[19]. SurachiKumar ,Appraisal of heavy metal concentration in selected vegetables exposed to different degrees of pollution in Agra, India. Environ.Monit. Assess. 2012. 10661-012.

[20]. Gray C W, McLaren R G, Roberts A H C, Condron L M, Cadmiumphytoavailability in some New Zeland soils, Australian Journal of Soil research 37:1999, pp 461-477.

[21]. Intawongse Marisa, Dean John R, Uptake of heavy metals by vegetable plants grown on contaminated soil and their bioavailability in the human gastrointestinal tract, Food Additives and Contaminants, January 2006; 23(1): 36-48 